\title{
Indonesian Assessment Communicatively For Foreign Students
}

\author{
${ }^{1 s t}$ Laily Nurlina \\ Universitas \\ Muhammadiyah \\ Purwokerto \\ lailynurlina@ump.ac.id
}

\author{
${ }^{2 n d}$ Andayani; St.Y. \\ University of \\ SebelasMaret
}

andayani.staff@uns.ac.id

\author{
${ }^{3 r d}$ Retno Winarti \\ University of \\ SebelasMaret
}

winarniuns@yahoo.com

\author{
${ }^{4 t h}$ Slamet \\ University of \\ SebelasMaret
}

slametsty@yahoo.co.id

\begin{abstract}
The objectives of these research are (1) to describe assessment tool in BIPA before research, (2) to produce appropriate assessment tool for BIPA students to measure the real competence and (3) to produce assessment tool integrated four skills such as listening, speaking, reading and writing.BIPA Institution - UMP uses assessment by separating four skills so the students' competence can not measure well and accurately. The researcher advance some tests to integrate four skill by communicative approach so the students can explore their competence maximally. We describe some tes and non test assesmentso the BIPA teachers can advance based on their needs.The suggestion and recomendation are these simple assessment tools can be advanced in every BIPA institutions. Progress report must be given to complete the students' achievement.
\end{abstract}

Keywords : assessment, communicative, BIPA, progress report

\section{INTRODUCTION}

The implementation of BIPA learning (Indonesian for Foreign Speakers) has been carried out at the beginning of September since 2012 to prepare foreign students to receive lectures at the Muhammadiyah University of Purwokerto. This learning is carried out for only a maximum of one month so there is no standard assessment tool to measure the ability of foreign students or evaluate the learning process.

There were 22 foreign students from Southern Thailand and one from South Korea who was studying in various UMP study programs in 2014, and one from South Korea who was studying BIPA regularly. World Class University has become a challenge so that lecturers are required to always improve knowledge, knowledge, technology and the International Affairs Office that manages BIPA must be professional and improve the quality of teaching services.

One of the recommendations made at the Chancellor's Forum on October 18, 2014 was to require foreign nationals to become proficient in Indonesian before studying or working in Indonesia. This shows how strategic the role of BIPA and the opportunities - the Indonesian language opportunities to develop into an international language in the 2015 AFTA (Asean Free Trade Area). Purwokerto is better known as a city of education not industry but does not rule out the possibility of many students from foreign countries will study in this city. Around Purwokerto, there are Purbalingga and Cilacap which have long been industrial cities so that many foreign workers will be interested in working in the area. BIPA will also be increasingly needed because the UMP is still the only university that provides BIPA services in the southern part of Central Java.

Learning Indonesian for students from Southern Thailand and South Korea is learning a second language because they previously have a mother tongue (native language). Learning is implemented, of course, different from learning Indonesian in general so that teachers are required to have the ability to teach and develop appropriate evaluation tools. BIPA's evaluation tool is a necessity because with the courage of UMP to receive a BIPA participant from South Korea this year, it is certain that BIPA's echo has begun to be heard from word of mouth, especially among expatriates.

BIPA participants who are currently studying BIPA named Cho Seung Hee, wife of a false eyelash entrepreneur based in Purbalingga, has a Korean community so that all learning processes are often asked by Koreans working in Indonesia. Cultural differences between Indonesia and South Korea are unique because the demands of excellent service are always requested by consumers. Learning evaluation is carried out every month so that it requires appropriate assessment tools and describes the real abilities of BIPA participants. When a test differs from the level of difficulty with other tests, Cho Seung Hee will ask for the validity of the test. At the moment in the beginning of 2015 there was one BIPA participant from South Korea so that efforts to improve the quality of learning must be carried out more seriously.

In accordance with the formulation of the problem, the research objectives to be achieved are (1) 
describing the assessment tools used in BIPA learning before research is conducted, (2) producing the right assessment tools for BIPA learners so that they can measure actual learner abilities, and (3) produce assessment tools that include 4 language skills: listening, speaking, reading, and writing.

Literature review

Language is a tool that humans use to communicate so that they can be connected with each other. The problem of testing foreign language skills becomes interesting to discuss because Indonesian has become one of the languages of interest for foreign speakers to learn. When foreigners work or study in Indonesia there are two choices that can be taken using Indonesian or using the services of an interpreter in communication. If he chooses to use Indonesian, he must learn Indonesian so that he can also understand the culture, science, and technology contained in it.

The learning process - teaching Indonesian by foreign speakers is certainly not the same as when learning a mother tongue. Someone learns a foreign language when he has mastered his native language and has a language system in mind. Indonesian language learning for foreign speakers is often just simply translating mother tongue into Indonesian so that he will have difficulty communicating contextually and adapting to local culture. When the instructor will evaluate the learner's ability, it is difficult to determine the right evaluation tool.

Suwandi (2010: 9) defines assessment as a process to find out whether the process and results of an activity program are in accordance with the objectives or criteria set. Evaluation is the overall assessment of education including the planning of an education substance program including curriculum and assessment and its implementation, procurement and improvement of teacher capacity, management (management) education, and overall education reform. Thus, it is clear that assessment is part of the education evaluation (Ministry of National Education, 2002: 3).

Bexter (2011) suggested a number of reasons regarding the importance of assessment in learning. First, to compare students with other students. Second, to find out whether students meet certain standards. Third, to help students' learning activities and fourth, to find out or control whether the learning program is running properly. Assessment or tests like this to analyze errors that are generally carried out by students so that they can be used as a basis for deciding whether or not to change the educational program or learning program that has been done. Teachers can do remidial teaching or enrichment to maximize the ability of foreign students to achieve the minimum set value. Enrichment is done to give foreign students more opportunities to master Indonesian.

Assessment is an activity that must be carried out by the teacher as part of the teaching system that is planned and implemented in the classroom. The main components of the assessment include gathering information, interpreting the information that has been collected, and making decisions. The three components are interrelated and before doing so the teacher must determine or formulate the objectives of the assessment as described as follows:

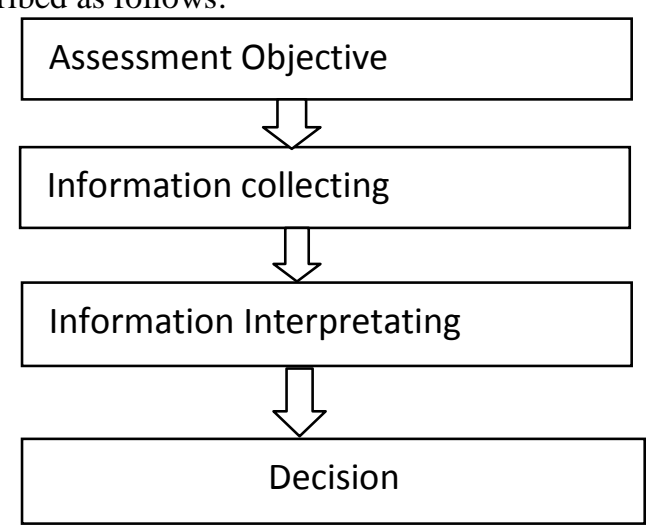

Picture 1: Assessment Aspects

Suwandi (2010) says the test is a way to do an assessment in the form of tasks and must be done by students. To get data about student grades and achievements by comparing the scores or achievements obtained with the standards set.

In Rebecca's statement, some basic abilities that should be mastered by foreign speakers when learning a second language, such as oral ability, are the ability to get to understand what the native speaker is talking about when speaking from simple to general. The ability to speak on topics that have been prepared without clear explanation, and the use of general expressions around foreign countries, speak with clear pronunciation. Reading skills can be seen from the ability to understand directly (untranslated) and writing skills that is writing sentences and paragraphs properly and correctly such as developing classroom situations and writing short and simple letters.

Nurgiyantoro explained several types of tests including (1) initial ability tests, (2) diagnostic tests, (3) formative tests and (4) sumative tests. In BIPA, it is recommended that the initial ability test is pre-test, prerequisite test and placement test. Each test has its function like pretest is a kind of initial ability test that is done before students experience the teaching and learning process and the results can be used to determine policies in carrying out teaching and learning activities. The prerequisite test is a test to find out whether students have certain abilities / skills and placement tests to determine the level of students' Indonesian language skills so that they can be grouped according to their abilities.

After the initial ability test, the teacher carries out diagnostic tests to find material that is still considered difficult by students. This student's weakness information will provide input for the teacher to determine the next teaching material and implement a remidial program. Formative tests are carried out during teaching and learning activities taking place or at the end of a subject. The function of this test is to measure the level of students' 
ability to achieve goals related to the subject matter and is a very useful input for teachers to assess the effectiveness of learning activities.

Furthermore, what is no less important is the summative test which is carried out after all teaching and learning activities have been completed or all planned programs. The material tested is all the material that has been taught. The function of this test is to measure levels of achieving learning objectives.

Some types of tests above can be modified in the making of BIPA learning assessment tools and tailored to the needs of learners. Every BIPA learner has his own learning objectives and cannot be equated with each other. For that the teacher is more concerned with the characteristics of each student so that the learning process can run according to their needs.

\section{METHODS}

Every learning activity requires a reference to monitor its success. In reference education science is commonly referred to as evaluation. BIPA also needs an evaluation tool, Widodo in ImronRosidi said that BIPA learning is often faced with the problem of learning evaluation, both process evaluation and evaluation of learning outcomes. Problems that are often faced by teachers: the form, type, and qualifications of measuring instruments used. This condition will always be experienced by the teacher when conducting a level determination test, both for the purpose of placement tests, pre-tests, and final test programs (Rosidi, 2009).

The form of evaluation measuring instrument can be made in the form of tests or non-tests if using a communicative approach. The form of measuring instruments in the form of tests can be used to test competencies (1) structure and expression of writing, (2) vocabulary and reading, and (3) listening. While for the nontes form is used to test competence (1) speaking and (2) write / compose a theme. Assessment through observation for measuring competence in speaking and writing. Scoring is used as an observation sheet that has a scale with clear indicators.

Communicative learning requires a communicative assessment tool as well. Teaching Indonesian as a foreign language to foreign speakers uses language as a particular communication rather than simply imparting language knowledge. Consequently, testing the ability to communicate in a foreign language must also measure the ability of learners to carry out certain tasks using the language they master. Therefore, tests that measure the ability to communicate are not the same as traditional tests that measure more traditional language (the rules of language).

Testing is a process or action to check ability, and in the field of teaching the abilities examined are learning outcomes. In language teaching including BIPA teaching, testing is conducted to measure language knowledge such as pronunciation, vocabulary, and grammar, as well as the four language skills of listening, speaking, reading and writing. In teaching communication skills, testing is carried out in an integrated (integrative) manner so that knowledge of language and skills is no longer measured alone - as if it were an ability that had nothing to do with each other. Integrated measurement, that is, measures the learner's ability to use language to communicate, and by itself language knowledge and communication skills are both measurable.

Some alternative assessment test tools used by foreign students to measure Indonesian language skills:

1. Read hard

This technique is often used to measure Indonesian pronunciation by foreign students. To measure pronunciation there are several tests that can be used by the teacher (Madsen, 1983), one of which is oral repetition. The method of repetition is very suitable for beginners who have just known Indonesian. For example:

Teacher: I like to drink coffee.

Student: (repeats) I like to drink coffee.

Learner assessment indicators can mimic the intonation, pronunciation, and accuracy of words per word with a range of $0-10$.

2. Grammar Test

This test is to measure the Indonesian grammar skills of foreign students, various forms of tests such as filling in dots, multiple choices, making sentences or combining sentences.

Problems example :

ibu's father went to Surabaya this afternoon.

- ___ your aunt works every day? In the hospital.

a. How b. Where is c. Who

- (Teacher said) Lisa ate Baso. (Student) What does

Lisa eat?

- Combine 2 sentences using the right conjunctions!

The girl is a dangdut singer. His voice is very melodious.

3. Complete the sentence

This test is in imperfect sentences and students complete with the correct grammar or complement by considering the coherence of the story. Choices are made and randomized in such a way as to prevent students from choosing because they try and not be serious.

Sample questions: Complete the following sentence with the words available! the wearer and the quality will be if

4. Guided essays

Students are asked to make essays according to the key words given by the teacher. The ability of students to express their ideas in foreign languages appropriately is the language ability. Examples of guided essay assignments: 
Write a letter to your friend and invite him to come to Purwokerto. Tell me that in Purwokerto there is a Baturaden with beautiful scenery, rivers, rice fields and beautiful landscapes. Many traditional foods that can be tried and taste good - delicious.

5. Questions and Answers

Teachers can ask questions and foreign students answer. Students can be given first themes or spontaneous themes from the teacher / examiner. Value indicators can take the form of students' understanding of questions, grammatical abilities, word choice (diction) and intonation.

In addition to themed questions, the teacher can do a question - answer using pictures and students answer questions according to the picture. For example, students are given pictures of conditions in traditional markets:

-What picture is this?

- Which do you think is the seller? Why?

- What are they doing there?

\section{Retelling}

This test is more assessing the speaking skills of foreign students in telling what they know about a theme. Students retell the pleasant or sad personal experience so that they can be seen in the ability to compose sentences, proper grammar, the right choice of words and so on

For lower classes, students are asked to read or listen to a story. After that, students retell the content of the story assuming that students have attended learning within a certain period of time and mastered simple grammar and vocabulary.

\section{Communication Game}

In the communication game test, the teacher prepares many games to test the communication skills of foreign students, for example, snakes and ladders, monopoly, guessing words, or other games that are modified so that they can be used for testing. Students will feel happy because this type of test does not make them tense and stressful so they are expected to truly reflect the ability to master language.

Alternative games for example by giving a choice of pictures and students choose one picture. Students explain or describe the picture to other foreign students. Images have been prepared so students can use the grammar that they want to test.

8. Oral Interview

Teachers can make tests in the form of oral interviews so that students can answer questions related to the context around the student. For example interviews about job applications, school or university entry interviews or other.
9. Role Games

Role playing can be used as a language skills test in groups so that students work with other students to implement it. For example the examiner gives a description of the doctor and patient, the student plays it. The examiner makes an assessment indicator and a range of values to make accurate values that illustrate the ability of Indonesian language.

10. Free Authorship

One written test is to give students the opportunity to make free essays. From their writing, the teacher can analyze the ability of foreign students in Indonesian. There are many other methods that can be used by examiners to measure language skills that are adjusted to the level of ability of foreign students to communicate in Indonesian. The language skills of foreign students who are different in height and low need different assessment tools so that BIPA teachers must continue to develop their creativity. In addition to measuring language skills, testers can also use other types of tests to measure foreign students' language knowledge that can be adapted from TOEFL (Teaching of English for Foreign Language) or other standard tests used. Several test alternatives can be used:Look for grammatical errors This technique is by giving sentences which consist in part of sentences that have grammatical errors. Students identify these errors. Example: Students learn Indonesian on campus. A B C D

11. Search for and correct errors

Students look for mistakes and correct them. Examiners can see how they are in the grammar skills of foreign students. Examples of questions that are above the answer are A (students) and corrected to students or students.

\section{Language Perception Test}

Students are given a set of words and asked to enter into Indonesian or regional languages (Javanese). This test is to measure the perception and language understanding of foreign students in order to distinguish between the use of national languages and local (regional) languages.

\section{Card preparation}

This test can be used to test BIPA participants who are still children because they are happy with the game. The trick can be to make cards that contain words and learners compile to make correct sentences.

Differences in language knowledge measurement tools and language ability measurement tools can be seen from the types of tests. Language ability measurement tools are used to measure language skills while language knowledge measurement tools 
are more oriented to linguistic elements, such as grammar, vocabulary, conjunctions, prepositions and so on.

\section{CONCLUSION}

The BIPA learning assessment tool really needs to be developed in each BIPA institution with specificities and according to their individual needs. One that has been developed in this study can be used as a reference so that more varied types - types of assessment with a communicative approach for salty students.

\section{References}

Cresswell, John. 2010. Research Design : Qualitative, Quantitative, and Mixed Approaches. California : SAGE Publications

Ellis, Rod. 1986. Understanding Second Language Acquisition. New York: Oxford University.

Eltis, KJ. 1991. A Genre-Based Approach to Teaching Writing in Years 3-6. Australia : Commond Ground Publisher.

Griffin, Patrick et all. 2012. Assessment and Teaching of 21st Century Skills. Australia: Springer

Hastuti, Sri. 1989. Sekitar Analisis Kesalahan Berbahasa Indonesia. Yogyakarta : PT Mitra Gama Widya

Hayes,J.R. and L.S. Flower. 1986. Writing Research and the Writing. American Psychologist, 41(10): 1106 1113

Littlejohn. Andrew. 1991. Writing 1. Australia : Cambridge University Press

McMillan, James. 2012. Educational Research: Fundamentals for The Consumer. Boston: Pearson

Nikko, Anthony J. 2011. Educational Assessment of Students. Boston : Pearson

Nurgiyantoro, Burhan. 2010. Model Penilaian Otentik dalam Pembelajaran Bahasa. Yogyakarta: Unit Percetakan dan Penerbitan UNY

Riduwan. 2009. Metode dan Teknik Menyusun Proposal Penelitian. Bandung : Penerbit Alfabeta

Santrock. John W. 2007. Psikologi Pendidikan. Indonesia: Kencana Prenada Media Group

Straus, Corbin. 2009. Dasar - Dasar Penelitian Kualitatif. Yogyakarta :: Pustaka Pelajar

Sugiyono. 2011. Metode Penelitian Kuantitatif Kualitatif dan $R \& D$. Bandung : Penerbit Alfabeta

Suwandi,

Sarwiji.2010.PenilaiandalamPembelajaranAssessmen . Surakarta: Yuma Pustaka 